American Research Journal of English and Literature

ISSN (Online): 2378-9026

Volume 6, Issue 1, 2020, 1-4 Pages

DOI: 10.21694/2378-9026.20004

AMERICAN RESEARCH JOURNALS

An Academic Publishing Hause

\title{
Angelic Monsters: Psychoanalytic, Comparative Approach to Walpole's the Castle of Otranto and Shelley's Frankenstein
}

\author{
Fatima Aref Msheik \\ Department of English Literature, Beirut Arab University, Lebanon. \\ fatimamsheik@hotmail.com
}

\section{INTRODUCTION}

The Gothic genre is a well-known genre. It is a Taylor defines in his article "An Exploration of Origins of Gothic Fiction", "an exploration of the true, or 'other' self, but realized in the genre of horror, sexuality and perverse freedom of thought, seen to be detrimental to tight mores of 'cultured' society". The Castle of Otranto by Horace Walpole, and Frankenstein by Mary Shelley are considered the best of the gothic fiction novels. However, since the gothic fiction novels "preserve freedom of thought" and explore "the true of other self", they uncover the Id of thoughts and reveal its hidden desires in a frame of gothic. The Castle of Otranto is the first in the gothic genre. Frankenstein is considered a modern gothic novel. In these two novels the conflicts are an exploration of the conflicts in nature. Nature is the head of all conflicts. Within the nature arise the conflicts within the self and with the other. This conflict may be internal on one hand and external between the self and the other from the other hand. The question is how "the self" is defined, and how "the other" is defined? In our research, the self is defined as human nature, psychology and self; the other is defined as society, religion, and the other sex. In this research, I am going to demonstrate that the authors of the two novels uncover the Ids of Manfred, in the Castle of Otranto, and the Monster, in Frankenstein through the conflicts within self and with the other to show that they are both victims of the society, which symbolizes the superego.

\section{Methodology}

Freud's psychoanalytic theory is based upon the study of the personality structure into three different elements: id ego, and superego. The id represents the "pleasure principle" (Guerin, et al 156) where the internal and basic drives and needs are founded. The ego represents "reality principle" (157) and it balances between the id and the ego. The superego represents the "morality principle" (157); it judges our sense of wrong and right using guilt to encourage socially acceptable behavior. Freud also studies the "unconscious" which is the true feelings, emotions and thoughts of the individual. Meanwhile, Tatar explains the aspect of the "die wiederkehr des verdrangten", which is a Freudian expression that means "the return of what has been at once displaced and repressed" (172).

\section{Angelic Monsters in Both Novels}

The conflicts with the self, explain that Manfred and the monster are both victims of their society. These conflicts take place on the level of the id of both characters. First level of conflicts within the self is asking for an heir. Asking for an heir is an unconscious desire to survive; it is unconscious desire for immortality. Manfred's desire to have a child after the death of his son Conrad is an unconscious desire for immortality. The same desire is found in Frankenstein through the monster's desire to have a companion. His unconscious desire to have an heir is translated into the desire to have a companion. In this way, Walpole and Shelley uncover the id of both characters. Manfred wants an heir for his throne, so he is psychologically confused. This confusion is a reflection 
Angelic Monsters: Psychoanalytic, Comparative Approach to Walpole's the Castle of Otranto and Shelley's Frankenstein

of self-conflict of continuity that is translated through his act of intending to marry Isabella and divorce his wife. However, the monster's quest for an heir is somehow hidden by the desire to have a companion, and having a companion mean breeding and having an heir. Unfortunately, for both of them, no one succeeds to have an heir. Finally, the monster frees himself from the bondage of the self-conflict through his death with his creator Frankenstein. Manfred ends up not freeing himself, but imprisoning it forever in the prison of his failure to acquaint and overcome his conflicts within self. Also, the conflicts within self are reflected through the castle labyrinths that are one of the gothic elements which "can be used for variety of purposes" (Spector 1046) in The Castle of Otranto; the castle that represents the self, and the labyrinths within it that represent the conflicts within the self of Manfred precisely. This "castle" is replaced by "the scientific laboratories" (1046) in Frankenstein as Robert Spector says in his book The Gothic. Frankenstein is a more modernized gothic novel than The Castle of Otranto. The "castle" represents the conflicts within the self of Manfred; the "scientific laboratory" initiates the conflict within the self of the Monster because it is the place of its birth, the moment where all his agonies and conflicts begin. The natural desire of immortality is found within the Id of every person. Manfred and the Monsters are the victims of this unconscious desire that is enriched by the society unacceptance.

One of the most important aspects of the conflicts within self in both characters is what is known as "die wiederkehr des verdrangten", which is a Freudian expression that means "the return of what has been at once displaced [usurped] and repressed"(Tatar 172). In The Castle of Otranto, the return of Theodore is the return of the repressed truth and usurped throne; in Frankenstein, it is the return of the Monster, who was repressed and abandoned by Victor himself. The question of return of what has been at once displaced and repressed is not just a question of return according to Manfred; it is the fear or the consequences of the return of the past and Alfonso's ghost that is haunting him. It seems that this conflict is the conflict of "the survival of the Fittest". Manfred's conflict is the conflict of his feelings as a father, husband, and as a king. It is revealed through the death of his son Conrad, and the murder of his daughter Matilda. Manfred is stuck in the conflict between the love of the throne and the love of the family. He is in conflict whether to kill Theodore or to leave him, and in both cases he is not the winner. "Manfred's heart [is] capable of being touched"[Walpole 60] when he witnesses the reunion between Theodore and his father, but the same "heart" is called several times a "tyrant"(59) and a "savage inhuman monster" (101). Manfred's heart "being touched" shows that he has some goodness in his heart; he is not totally a monster. His society makes him a monster because it gives him power. Power corrupts, and when society gives power to Manfred he becomes a monster. Society makes Manfred a monster. So, Manfred is a victim of this society. In the conflict within the self, Manfred's desire to keep the throne conquers the "heart capable of being touched". This desire destroys him, his family and the throne. The conflict within himself arises from the fact that he knows very well that he is "the usurper" of the throne. He recalls the prophecy that says that the crown will return to its owner. However, the Monster's conflict within self in Frankenstein is a little bit different. The Monster's self-conflict arises from the questions "who was I? What was I? Whence did I come?" (Shelley 86).These questions are related to the desire of knowledge of his identity; this knowledge is repressed. It is repressed by Victor, the monster's creator. The repress of knowledge drives him to act in a savage way. He is not a monster; he is a victim of monstrosity that is spread in society. At the beginning of the novel, the monster is kind; he helps people in the cottage. However, the rejection of society to him makes him a monster. Thus, he is a victim of a society.

The conflicts between self and the other are clear through the conflicts of Manfred and the Monster with religion and church, society, and the other sex. It is a conflict of the id, represented by Manfred and the Monster, with the superego represented by society and religion. Walpole's gothic novel The Castle of Otranto explores the dark side of human reality. This dark side of human reality is considered to be the Id. The conflict between Manfred and church is represented in the conflict between Manfred and Father Jerome, the father of Theodore. The conflict is obvious in Jerome's shy stand against Manfred in his try to protect Isabella and save the life of his 
Angelic Monsters: Psychoanalytic, Comparative Approach to Walpole's the Castle of Otranto and Shelley's Frankenstein

son Theodore. Manfred is against the natural law of being and against the law of church or religion because he breaks the chain of being by usurping the throne and forcing Isabella to marry him. He challenges God by killing his daughter thinking that she is Isabella. However, he regrets killing her. He says "Can assassins forgive! I took thee for Isabella; but Heaven directed my bloody hand to the heart of my cild-oh! Matilda-I cannot utter it-canst thou forgive the blindness of my rage?" (Walpole 108). This shows that he is a victim of his rage and of society's corruption because he asks finally for forgiveness. The Monster's conflict with the religion is the conflict with the other; the other is "God". The Monster is the representative of the "fallen angel" as Harold Bloom says, and the conflict of the fallen angel is with God. His journey is considered "the hell in the paradise lost"(Gilbert \& Gubar 225), and the conflict of the people in the hell is with God because of their sinful deeds. But the question here is what the sins of the Monster are? The Monster is put in a conflict that he is not responsible for. In this conflict, he is paying for the sins of his creator. The real monster here is Victor, and the Monster is a victim.

Manfred and Monster are put in a conflict with society; the society that represents, according to Manfred his family, his enemies, and his people. The society represents the superego. This conflict leads him to lose his daughter Matilda and the throne. When Manfred's Id faces the superego of the society, the ego shall interfere to balance between the id and the superego. The ego is not found here, so a state of unbalance between Manfred and the society occurs. In his conflict with the society, he loses himself and the society. Whereas, the Monster's conflict with the society is a rebellion over the way the society reacts toward the Monster; it is the refusal of the Monster by society though he is good. His act of murder of William, Victor's brother, and Victor's father, and Elizabeth is a result of this conflict. In The Caste of Otranto, Alfonso avenges himself and conquered Manfred; in Frankenstein, the Monster avenges himself by killing himself and Victor. The unbalance between the id and the superego results in the destruction of both Manfred and the Monster.

Meanwhile, the conflict between the self of Manfred and the Monster, and the other is a conflict with the "other sex". The term other that "describes women status in patriarchal, andocentric cultures"(Pilcher \& Whelehen 90) as Simone De Beauvoir uses this concept. The other here is a silent witness; she is the victim, this is called "victimhood"(Johnson 47). Women, in the conflict between Manfred and the other, are the victim. Manfred wants to divorce his wife because she is "unfruitful"; he also kills Matilda his daughter blinded by anger; he wants to force Isabella to marry him. Some critics argue that this novel and the gothic novels in general focus of a a virtuous women under sexual threat. They consider the relationship of Manfred to Isabella as an incestuous relationship since Isabella is in the age of his daughter. Also, they consider that Isabella's fear of marriage from Manfred is a realistic fear because of what is known as Clandenstine marriage being those that fulfilled the Church's legal requirements of free consent and no legal impediments. Clandestine marriage makes marriage easier, so Manfred's marriage from Isabella is easier. Similarly, the Monster in Frankenstein is in conflict with the other in sense that he is in need for "the other", the woman companion; he cannot create her, nor find any creature like him. In Gilbert and Gubar's essay "On Milton's Influence", they mention the "disguised incest" (Bloom 98). The incestuous relationship is the relationship of Victor to Isabella who is considered his sister. Also, in the relationship that the monster wants to make with his companion, that Victor is intended to create, is an incestuous relationship. If Victor is going to create a companion for it, he is actually creating a sister for the monster. That is because Victor is the father of both of them, and the father brings brothers and sisters, not husbands and wives. Also again, woman is the victim and Elizabeth here is the victim. Finally, Walpole and Shelley remove the lid of "the other" that is society, religion, other self and nature, from the id of the selves of Manfred and the Monster. These actions and events reveal the conflicts that take place within the self, and the life of everybody of us; not necessarily in the same way, but in the same concept of conflicts. It causes at the end the freedom of the self because when the self reveals its conflicts, it is freed American Research Journal of English and Literature Page 4 Angelic Monsters: Psychoanalytic, Comparative Approach to Walpole's the Castle of Otranto and Shelley's Frankenstein from them whether it conquers them or be conquered by them. In

American Research Journal of English and Literature

Page 3 
Angelic Monsters: Psychoanalytic, Comparative Approach to Walpole's the Castle of Otranto and Shelley's Frankenstein

addition to the mentioned above, Classic Gothic becomes the perceived antithesis of the Catholic Church, that is, the resistance to religious laws in medieval times, up to the Victorian era in Britain, and more recently, Catholic Europe. This shows that Walpole and Shelley challenge their societies by creating the characters of Manfred and the monster to reconcile society with the self. Their trial is a quest for balancing the Id and the superego; it is a quest to uncover our Ids. What is literature but bringing the taboos into light and focusing on the unfocused?

\section{REFERENCES}

\section{Major Resources:}

Shelley, Mary. Frankenstein. U.S.A: N.N.Norton and Company INC., 1996. Print.

Walpole, Horace. The Castle of Otranto. U.S.A: Dover Publication, 1966. Print.

\section{Minor Resources:}

Gilbert, S., and S. Gubar. "Mary Shelley's Monstrous Eve." Frankenstein. U.S.A: N.N. Norton and Company INC., 1996. 225-40. Print.

Johnson, Tracy. "The Fear Industry: Women, Gothic and Contemporary Crime Narrative." Gothic Studies 4.1 (2002): 44-62. Web.

Pilcher, Jane, and Imelda Wheletter. Key Concepts in Gender Studies. Los Angeles ; London ; New Delhi ; Singapore; Washington DC; Melbourne: SAGE, 2017. Print.

Selden, Raman and Peter Widdowson. A Reader's Guide to Contemporary Literary Theory. 3rd Ed. Lexington: U of Kentucky P, 1993.

Spector, Robert Donald. Seven masterpieces of Gothic horror. New York: Bantam , 1971. Print.

Tatar, Maria. "The Houses of Fiction: Toward a Definition of the Uncanny." Comparative Literature 33.2 (1981): 167-82. Web.

Citation: Fatima Aref Msheik, "Angelic Monsters: Psychoanalytic, Comparative Approach to Walpole's the Castle of Otranto and Shelley's Frankenstein". American Research Journal of English and Literature, vol 6, no. 1, 2020, pp. 1-4.

Copyright (c) 2020 Fatima Aref Msheik, This is an open access article distributed under the Creative Commons Attribution License, which permits unrestricted use, distribution, and reproduction in any medium, provided the original work is properly cited. 